The University of Southern Mississippi

The Aquila Digital Community

Faculty Publications

$1-1-2007$

\title{
Antibacterial Fluoromicas: A Novel Delivery Medium
}

\author{
Bekir Dizman \\ University of Southern Mississippi \\ Jonathan C. Badger \\ University of Southern Mississippi \\ Mohamed O. Elasri \\ University of Southern Mississippi, Mohamed.Elasri@usm.edu \\ Lon J. Mathias \\ University of Southern Mississippi, Lon.Mathias@usm.edu
}

Follow this and additional works at: https://aquila.usm.edu/fac_pubs

Part of the Chemistry Commons

\section{Recommended Citation}

Dizman, B., Badger, J. C., Elasri, M. O., Mathias, L. J. (2007). Antibacterial Fluoromicas: A Novel Delivery Medium. Applied Clay Science, 38(1-2), 57-63.

Available at: https://aquila.usm.edu/fac_pubs/12448

This Article is brought to you for free and open access by The Aquila Digital Community. It has been accepted for inclusion in Faculty Publications by an authorized administrator of The Aquila Digital Community. For more information, please contact Joshua.Cromwell@usm.edu. 


\title{
Antibacterial fluoromicas: a novel delivery medium
}

\author{
Bekir Dizman, Jonathan C. Badger, Mohamed O. Elasri, Lon J. Mathias ${ }^{ \pm}$ \\ Department of Polymer Science and Department of Biological Sciences, The \\ University of Southern Mississippi
}

\begin{abstract}
Antibacterial fluoromicas were prepared by ion-exchanging fluoromicas with different antibacterial agents including various quaternary ammonium compounds, $\mathrm{AgNO}_{3}$, and norfloxacin. Antibacterial activities of the ion-exchanged fluoromicas were determined against Staphylococcus aureus and Escherichia coli. Minimum inhibitory concentration (MIC) and zone of inhibition (ZOI) tests were performed to determine both antibacterial effectiveness and mode of action associated with the fluoromicas. All treated fluoromicas showed excellent antibacterial activities against both types of bacteria. The antibacterial activities of treated fluoromicas were found to be either better than or the same as those of neat antibacterial agents. The repeated antibacterial activity tests demonstrated the extended activity of these systems.
\end{abstract}

${ }^{7}$ Corresponding author. Address: 118 College Drive, Polymer Science, The University of Southern Mississippi, Hattiesburg, MS, 39406-0076. Tel. +1-601-266-4871; fax: +1601-266-5504 E-mail address: Lon.Mathias@usm.edu 


\section{Introduction}

A substantial amount of work has been carried out on designing biomaterials, specifically polymers and surfaces that are inherently antibacterial. Most of these surfaces are generated by attaching antibacterial compounds directly to a substrate or incorporating antibacterial agents as pendant groups on polymer chains via covalent bonds. These materials have a wide variety of applications including but not limited to medical devices, clothing, countertops, and coatings. A few examples of antibacterial agents that have been used in new biomaterials pertinent to this research are quaternary ammonium compounds, fluoroquinolones, and silver nitrate (Baveja et al., 2004; Catauro et al., 2004; Dizman et al., 2005; Hume et al., 2004; Oie et al., 2004; Piddock et al., 2001; Samuel and Guggenbichler, 2004).

Quaternary ammonium compounds (QACs) are antibacterial agents used as both skin antiseptics and disinfectants (Borman, 2002; Chauhan et al., 2004; Lee et al., 2004; Richard et al., 1997). They generally contain a positively charged hydrophilic ammonium group and a long hydrophobic alkyl chain. It is believed that QACs kill bacteria by disrupting cell walls and/or inner bilipid membranes causing the cytoplasmic membrane contents of the cell to leak out (Birnie et al., 2000; Lee et al., 2004). The most active QACs contain alkyl chains that are between 8 and 18 carbons in length; e.g. compounds with 16 carbon alkyl chains are effective against both Gram-positive and Gram-negative bacteria (Birnie et al., 2000; Borman, 2002; Sauvet et al., 2000).

Another major class of antibacterial agents are antibiotic drugs. Norfloxacin is a broad spectrum chemotherapeutic antibiotic in the fluoroquinolone class. It forms a three membered complex with DNA, DNA gyrase, and DNA topoisomerase IV, which are 
responsible for relieving torsional strain in DNA during transcription and replication. The complex causes a variety of adverse interactions within the cell that ultimately lead to cell death (Dizman et al., 2005, Drlica, 1999).

Silver has also been used for years as a broad spectrum antibiotic for burn victims and in the eyes of newborns (Melaiye et al., 2004; Richard and Samuel, 1997). The $\mathrm{Ag}^{+}$, active form, precipitates proteins, inhibits a variety of enzymes, and has a negative effect on transport systems in membranes (Dibrov et al., 2002; Richard and Samuel, 1997). Silver has been incorporated onto glass surfaces, zeolites, and into catheters where it shows very promising antibacterial activity (Catauro et al., 2004; Rivera-Garza et al., 2000; Samuel and Guggenbichler, 2004). The structures of the antibacterial compounds used in this work are shown in Scheme 1.

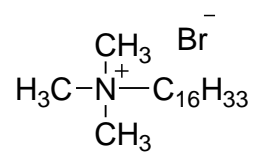

(CTAB)

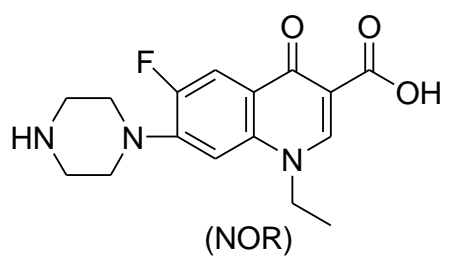

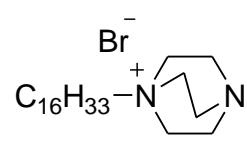

(C16-D)

Scheme 1. Typical antibacterial compounds

Clays are phyllosillicates composed of stacked sheets of nanosized, sandwich-like structures made primarily of silicon, oxygen and other metals. The interlayer of each sheet contains $\mathrm{Al}, \mathrm{Mg}$ and related elements along with negative charges that are balanced with exchangeable cations on the surface such as $\mathrm{Na}^{+}, \mathrm{K}^{+}$, and $\mathrm{Li}^{+}$. The amount of exchangeable cations per mass unit is called the cation exchange capacity (CEC). This 
unique electrostatic arrangement allows the surface cations of clays to be exchanged with organic cations. Dispersion of such organoclays is useful in enhancing the mechanical properties of polymers (Heinz and Suter, 2004; Heinz et al., 2003).

There are relatively few publications pertaining to organically-modified clay minerals showing antibacterial activity. The previous work that exists has focused on QAC modified clays and their uses in water purification and cosmetics (Alther, 2001; Guilbeaux, 1988; Herrera et al., 2000; Herrera et al., 2004).

In this study, we report specifically on the antibacterial activity of fluoromicas exchanged with various QACs containing 16 carbon alkyl chains, $\mathrm{AgNO}_{3}$, and norfloxacin.

\section{Materials and Methods}

\subsection{Materials}

Norfloxacin, 1,4-diazabicyclo[2.2.2.] octane (DABCO), 3-quinuclidinol, and cetyltrimethylammonium bromide (CTAB) were obtained from Sigma-Aldrich Chemical Company. SOMASIF ME-100 synthetic fluoromica (CEC 70-110 mequiv./ 100g (Murayama et al., 2002; Tamura et al., 2000) was purchased from UNICOOP Japan. Silver nitrate $\left(\mathrm{AgNO}_{3}\right)$ and all solvents were purchased from Sigma-Aldrich Chemical Company, Acros Chemical Company, or Fisher. Triptic soy agar (TSA) and triptic soy broth (TSB) were purchased from Difco Laboratories. Bacterial strains used for antibacterial activity tests included S. aureus and E. coli strain. The strains were kept at $80{ }^{\circ} \mathrm{C}$ in a freezer. $\mathrm{C} 16-\mathrm{D}$ and $\mathrm{C} 16-\mathrm{Q}$ were prepared by reacting $\mathrm{DABCO}$ and 
quinuclidinol, respectively, with 1-bromohexadecane using a literature procedure (Dizman et al., 2004).

\subsection{Measurements}

${ }^{13} \mathrm{C}$ and ${ }^{1} \mathrm{H}$ NMR solution spectra were recorded on a Bruker AC-200 spectrometer at room temperature using $\mathrm{CDCl}_{3}$ and $\mathrm{D}_{2} \mathrm{O}$ as solvents with tetramethylsilane (TMS) as internal reference. Fourier transform infrared spectra (FTIR) were obtained using a Mattson 5000 spectrometer using pressed $\mathrm{KBr}$ pellets. Thermal analyses were performed on a TA Instruments 9900 analyzer equipped with a 952 thermal gravimetric analyzer cell using heating rates of $20{ }^{\circ} \mathrm{C} / \mathrm{min}$ to $800{ }^{\circ} \mathrm{C}$ in air. Antibacterial assays were incubated in a Gyromax 737 shaker at $37^{\circ} \mathrm{C}$ with a gyration speed of $220 \mathrm{rpm}$.

\subsection{Preparation of Antibacterial Fluoromicas}

Exact amounts of fluoromica and antibacterial compound used for preparation of each nanocomposite are provided in Table 1. A sample of fluoromica was weighed and suspended in $100 \mathrm{~mL}$ of deionized water using a magnetic stir bar. The antibacterial compound, whose amount was determined using the formula below, was then added to the suspension to provide an excess of cations for the exchange. The suspension was then stirred vigorously at ambient temperature for $24 \mathrm{~h}$.

Amount of Antibacterial Agent $=\frac{\text { (Amount of Clay) }}{100 \mathrm{~g}} \times(\mathrm{CEC}) \times(\mathrm{MW}$ of Antibacterial Agent $) \times(1.1)$

CEC is the cation exchange capacity for clay, which is 110 mequiv. for fluoromica.

For the clay exchanged with norfloxacin, $5 \% \mathrm{HCl}$ solution was added into the flask containing norfloxacin to protonate the amine function of norfloxacin and make it both 
water soluble and exchangeable with the fluoromica cations. After $24 \mathrm{~h}$, the suspensions of the fluoromicas treated with QACs were filtered and resuspended in $100 \mathrm{~mL}$ of deionized water for $1 \mathrm{~h}$. The suspensions of fluoromicas with silver and norfloxacin were filtered, washed, resuspended in deionized water, and centrifuged a minimum of three times. The solid products obtained were filtered, dried in a vacuum oven at ambient temperature, and reground with a mortar and pestle.

Table 1. The amounts of fluoromicas and antibacterial compounds

\begin{tabular}{|c|c|c|c|}
\hline Compound & $\begin{array}{c}\text { Fluoromica } \\
(\mathbf{g})\end{array}$ & $\begin{array}{c}\text { MW of } \\
\text { compound } \\
(\mathbf{g} / \mathbf{m o l})\end{array}$ & $\begin{array}{c}\text { Mass of compound used } \\
(\mathbf{g})\end{array}$ \\
\hline $\mathrm{AgNO}_{3}$ & 0.28 & 169.87 & 0.06 \\
\hline $\mathrm{NOR}$ & 0.26 & 319.33 & 0.10 \\
\hline $\mathrm{CTAB}$ & 4.95 & 364.45 & 1.91 \\
\hline $\mathrm{C} 16-\mathrm{D}$ & 0.22 & 417.51 & 0.11 \\
\hline $\mathrm{C} 16-\mathrm{Q}$ & 0.21 & 432.52 & 0.11 \\
\hline
\end{tabular}

\subsection{Antibacterial Assessment}

\subsubsection{Preparation of bacterial cultures}

Broth cultures of $S$. aureus and $E$. coli were prepared from streaks on agar plates. A sterile wire loop was used to take a small sample of bacteria from the agar plate. Each bacterial sample was placed into a culture tube containing $5 \mathrm{~mL}$ of TSB. The inoculated tubes were incubated at $37{ }^{\circ} \mathrm{C}$ with shaking for $24 \mathrm{~h}$. Concentrations of bacteria were measured by optical density at $600 \mathrm{~nm}$. A standard curve was used to estimate the number of colony forming units (CFUs) used in the experiments (data not shown).

\subsubsection{Antibacterial assessment of neat and treated clays}


Two samples of each neat and treated clays were suspended in TSB at a concentration of $5 \mathrm{mg} / \mathrm{mL}$ in culture tubes. Each sample was then tested for antibacterial effectiveness against both $S$. aureus and $E$. coli by inoculating the tubes with $10^{5}$ CFUs of bacteria. The culture tubes were incubated at $37^{\circ} \mathrm{C}$ with shaking for $24 \mathrm{~h}$. A $100 \mu \mathrm{L}$ aliquot was then taken from each tube, spread on a TSA plate and incubated at $37{ }^{\circ} \mathrm{C}$ for $24 \mathrm{~h}$. The TSA plates were examined for bacterial growth and compared with the plates of control samples. After the first trial, the samples were washed 3 times with $10 \mathrm{~mL}$ portions of deionized water. The fluoromicas were suspended and centrifuged in each wash. A second trial was then run using the washed samples under the same conditions.

\subsubsection{Zone of inhibition (ZOI) test}

Both parent compounds and their treated fluoromica counterparts were used for testing. Agar plates were inoculated with $10^{6}$ CFUs of $S$. aureus (in $100 \mu \mathrm{L}$ of TSB). Small, circular wells were dug into the agar plates using the back end of a $100 \mu \mathrm{L}$ pipette tip. $2 \mathrm{mg}$ of each sample was suspended or dissolved in $100 \mu \mathrm{L}$ of TSB and placed into the wells. The plates were then placed in an oven at $37^{\circ} \mathrm{C}$ for $24 \mathrm{~h}$. The diameter of the zone of inhibition was then measured to the nearest $\mathrm{mm}$.

\subsubsection{ZOI test for CTAB treated clay washed with $1 \% \mathrm{NaCl}$}

A $100 \mathrm{~mL}$ solution of $1 \%$ aqueous $\mathrm{NaCl}$ was prepared and a $1 \mathrm{~g}$ sample of $\mathrm{CTAB}$ treated clay was suspended using high agitation stirring with a magnetic stir bar for a period of $30 \mathrm{~min}$. The fluoromica was then filtered using suction filtration and washed with small portions of distilled water. A small portion of the solid sample was collected for ZOI test and the process was repeated 3 additional times using the remaining sample 
to give a total of 4 samples. The samples were dried and TGA was run on each one to determine the percentage of organic material remaining on the fluoromica.

A TSA plate was inoculated with $10^{6} \mathrm{CFUs}$ of $S$. aureus and small circular wells were dug into the agar using the back end of a $100 \mu \mathrm{L}$ pipette tip. Washed samples $(5 \mathrm{mg})$ were each suspended in $250 \mu \mathrm{L}$ of TSB and a portion of each suspension was added to the dug wells in the agar plate. The plate was then incubated at $37{ }^{\circ} \mathrm{C}$ for $24 \mathrm{~h}$. Results were examined on a qualitative basis for growth.

\subsubsection{Minimum inhibitory concentration (MIC) test for treated clays}

The MIC values of treated clays were determined by the broth dilution method using serial twofold dilutions in TSB. The concentrations ranged from $256 \mu \mathrm{g} / \mathrm{mL}$ to 0.5 $\mu \mathrm{g} / \mathrm{mL}$. Each solution in the series was mixed with $10^{5} \mathrm{CFU}$ of the test organism in a 96well microtiter plate. The 96 -well plate was incubated at $37{ }^{\circ} \mathrm{C}$ for $24 \mathrm{~h}$. The MIC test was repeated at least three times for each treated clay.

\section{Results}

\subsection{Verification and evaluation of cation exchanges with fluoromica}

The amounts of the antibacterial compounds used for the cation exchanges were determined using the formula given in the experimental section. A 1.1x excess of each antibacterial agent was used in order to achieve the maximum cation exchange.

FTIR and TGA were run on all exchanged samples to verify success of the cation exchange. Figure 1 shows the FTIR spectra for neat fluoromica, norfloxacin-treated fluoromica, and CTAB-treated fluoromica. The presence of symmetric and 
antisymmetric streching peaks of $\mathrm{CH}, \mathrm{CH}_{2}$, and $\mathrm{CH}_{3}$ groups at $2900-3000 \mathrm{~cm}^{-1}$ and their deformation peaks at $1470 \mathrm{~cm}^{-1}$ indicate that the exchange with CTAB cations was successful. Similar spectra were obtained when C16-D and C16-Q were used for the treatment of the fluoromica. All the norfloxacin peaks were observed in the spectrum of the norfloxacin-treated fluoromica (Dizman et al., 2005).

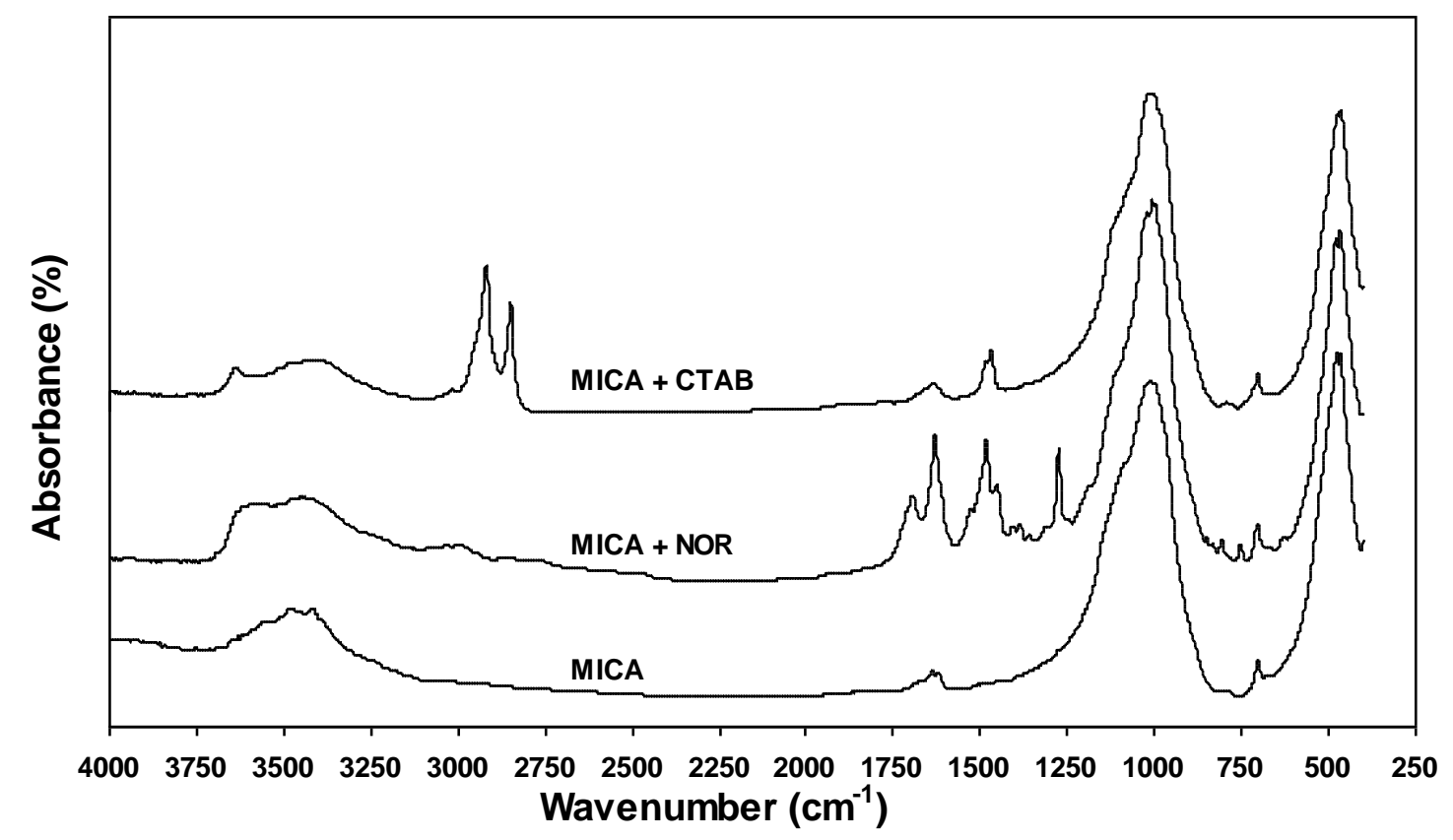

Figure 1. FTIR spectra of fluoromica, norfloxacin-treated fluoromica, and CTABtreated fluoromica

Thermogravimetric analysis (TGA) was used to determine the organic content of the modified fluoromica samples. The TGA thermograms in Figure 2 show two mass losses for each compound. The first mass loss between 0 and $100{ }^{\circ} \mathrm{C}$ corresponds to loss of water. The second mass loss observed for all samples except the silver-treated fluoromica, showed a loss that corresponded to degradation of organic materials bound to the fluoromica. The table inside Figure 2 shows both water and organic content for all samples. 


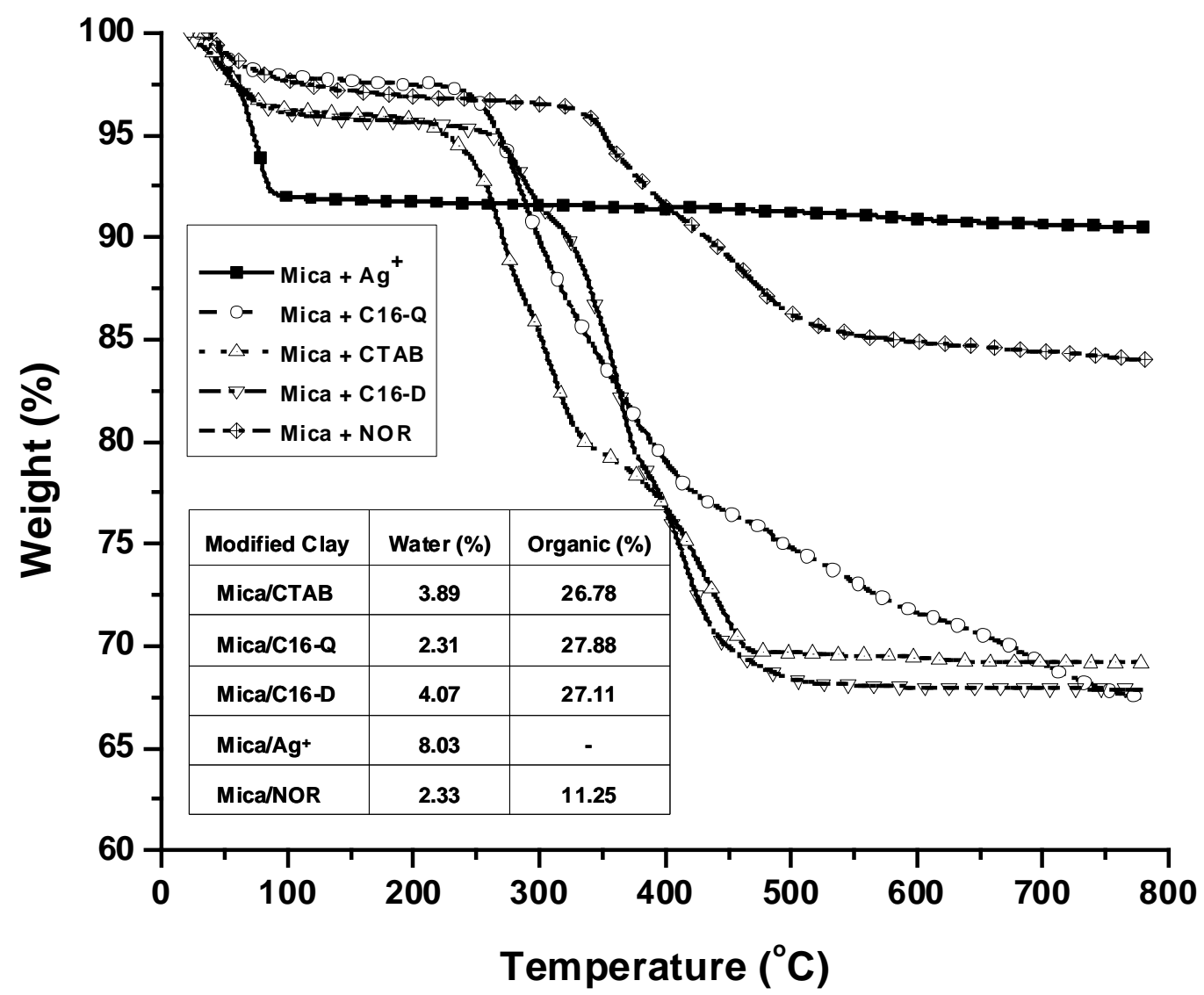

Figure 2. TGA thermograms of organically treated fluoromicas (interior table shows water and organic content of the treated fluoromicas)

Table 2 shows the amount of cation exchange expressed as a percentage. TGA data from the table inside Figure 2 was used for each calculation. First, the mass losses associated with water and organic material in the samples were subtracted from the total sample mass yielding the mass of the fluoromica in the samples. Next, the molar equivalent of exchangeable cations was calculated by multiplying the CEC value of the fluoromica by the mass of fluoromica. Finally, the number of moles of organic material on the surface of clay was calculated from the mass loss data and divided by the number of exchangeable sites giving the percent success of the exchange. TGA data for the QAC 
treated fluoromicas indicated that more than $100 \%$ of the CEC had been exchanged with organic material except for norfloxacin. One of the reasons for such high percentages is that there are associations that are nonionic in nature. Additional QACs may simply be associating with already bound organics via hydrophobic interactions. Additionally, water, organic material, or other impurities in the original fluoromica or reagents, incomplete eliminations in TGA, variable CEC, and other experimental errors can result in high exchange rates. The cation exchange percentage was however a little bit lower for norfloxacin. This might be due to the aromatic structure of norfloxacin, which can make its diffusion into the clay interlayers more difficult. Moreover, norfloxacin has a zwitterionic nature and this can result in a weaker binding to clay compared to the other strongly ionic agents.

Table 2. Cation exchange percentages for compounds

\begin{tabular}{|c|c|}
\hline Compound & Exchange (\%) \\
\hline CTAB & 123 \\
\hline C16-D & 106 \\
\hline C16-Q & 103 \\
\hline $\mathrm{Ag}^{+}$ & - \\
\hline NOR & 37 \\
\hline CEC value of 110 mequiv / 100g was used \\
\hline Calculations were based on mass loss data from TGA \\
\hline
\end{tabular}

\subsection{Antibacterial assessment of neat and treated clays}

The initial screening of treated clays showed that all silver, quaternary ammonium, and norfloxacin treated clays kill both $E$. coli and $S$. aureus at a concentration of 5 $\mathrm{mg} / \mathrm{mL}$, whereas neat clay did not show any antibacterial activity. After washing the 
treated clay samples with distilled water, the samples maintained their activity and were just as effective in the second trials.

\subsubsection{Zone of inhibition (ZOI) test results}

The results from the zone of inhibition tests are given in Table 3. The diameter of the zone of inhibition and the amount of diffusion from the edge of each hole in the agar plate are given in mm. Both the treated clays and parent antibacterials by themselves showed some degree of diffusion. The zone of inhibition for each of the treated clays was consistently less than each of the antibacterials alone, consistent with lower available concentrations of clay-bound agents. The QAC and silver samples showed far less diffusion as compared with the norfloxacin samples. The ZOI results for the neat norfloxacin and norfloxacin-treated fluoromica samples are shown in Figure 3.

Table 3. Zone of inhibition test results

\begin{tabular}{|l|c|c|c|}
\hline Compound & $\begin{array}{c}\text { Initial Hole Diameter } \\
(\mathrm{mm})\end{array}$ & $\begin{array}{c}\text { Final Inhibition Zone } \\
\text { Diameter }(\mathrm{mm})\end{array}$ & $\begin{array}{c}\text { Diffusion } \\
(\mathrm{mm})\end{array}$ \\
\hline CTAB & 8 & 14 & 3 \\
\hline Fluoromica + CTAB & 8 & 9 & 0.5 \\
\hline C16-D & 8 & 13 & 2.5 \\
\hline Fluoromica + C16-D & 8 & 9 & 0.5 \\
\hline C16-Q & 8 & 11 & 1.5 \\
\hline Fluoromica + C16-Q & 8 & 9 & 0.5 \\
\hline Ag+ & 8 & 14 & 3 \\
\hline Fluoromica + Ag+ & 8 & 11 & 1.5 \\
\hline NOR & 8 & 37 & 14.5 \\
\hline Fluoromica + NOR & 8 & 26 & 9 \\
\hline
\end{tabular}




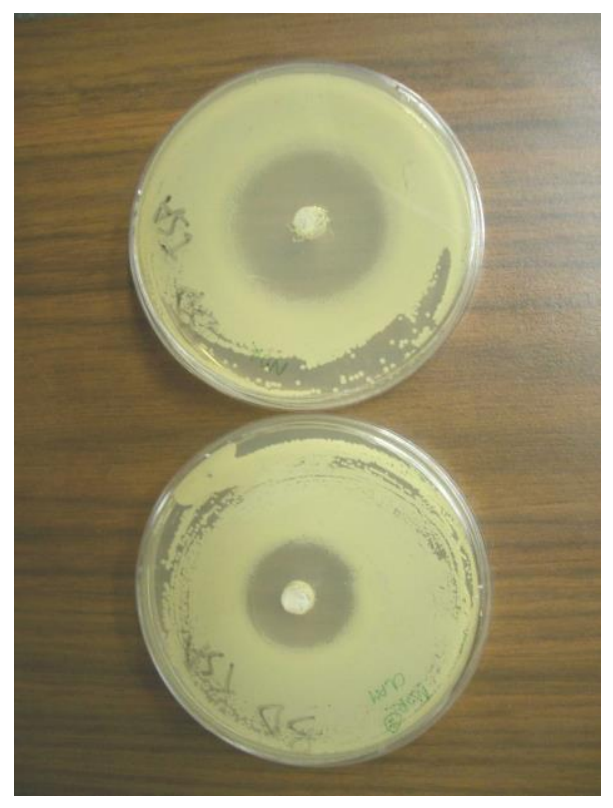

Figure 3. ZOI test results for norfloxacin (top) and NOR-treated fluoromica (bottom)

\subsubsection{ZOI test results of CTAB treated fluoromica washed with $1 \% \mathrm{NaCl}$}

The TGA data for the washed samples indicate that even after 4 washings with a $1 \%$ $\mathrm{NaCl}$ solution the amount of organic material bound the clay remained the same (see Table 4). This is consistent with the qualitative results from the zone of inhibition test in which the diameter of inhibition for each of these washed samples was the same.

Table 4. Organic and water content of CTAB-treated fluoromica after each wash with $1 \% \mathrm{NaCl}$

\begin{tabular}{|c|c|c|c|}
\hline Wash \# & Sample mass (mg) & Water Content (\%) & Organic content (\%) \\
\hline 1 & 8.32 & 9.38 & 25.16 \\
\hline 2 & 9.38 & 4.93 & 24.81 \\
\hline 3 & 8.49 & 5.92 & 25.36 \\
\hline 4 & 7.79 & 5.02 & 26.9 \\
\hline
\end{tabular}




\subsubsection{Minimum inhibitory concentration (MIC) test results for treated clays}

MIC values of all treated clays against $S$. aureus and E. coli are given in Tables 5 and 6 , respectively. Some samples showed a consistent MIC value for each of the three trials while others showed more variation. MIC values for samples that contained variations are given as a range. The concentrations of available antibacterials in each treated fluoromica sample were calculated by multiplying the percentage of total organic material in the composite by the MIC value of the composite. These MIC values were compared with the MICs of the neat antibacterial agents (last column). The MICs for CTAB, C16-Q, C16-D, silver, and norfloxacin were determined using the same procedures. When the last two columns (amount of antibacterial agent in the treated fluoromicas at the MIC values and antibacterial activity of neat compounds, respectively) in Tables 5 and 6 are compared it is observed that all treated clays either showed better activities than or were as effective as the parent compounds except norfloxacin-treated clay.

Table 5. MICs for treated fluoromicas and parent compounds against $S$. aureus

\begin{tabular}{|l|l|l|c|c|}
\hline Compound & $\begin{array}{l}\text { Organic } \\
\text { Content }(\%)\end{array}$ & $\begin{array}{l}\text { MIC of treated } \\
\text { mica }(\mu \mathrm{g} / \mathrm{mL})\end{array}$ & $\begin{array}{l}\text { Available antibacterial } \\
\text { concentration }(\mu \mathrm{g} / \mathrm{mL})\end{array}$ & $\begin{array}{l}\text { MIC of antibacterial } \\
\text { compound }(\mu \mathrm{g} / \mathrm{mL})\end{array}$ \\
\hline CTAB & 26.78 & $2-8$ & $0.5-2$ & 2 \\
\hline $\mathrm{C} 16-\mathrm{Q}$ & 27.88 & 4 & 1 & 2 \\
\hline $\mathrm{C} 16-\mathrm{D}$ & 27.11 & $4-8$ & $1-2$ & 2 \\
\hline $\mathrm{Ag}^{+}$ & - & $32-64$ & - & 16 \\
\hline $\mathrm{NOR}$ & 11.25 & 16 & 2 & 1 \\
\hline
\end{tabular}


Table 6. MICs for treated fluoromicas and parent compounds for E. coli

\begin{tabular}{|l|c|c|c|c|}
\hline Compound & $\begin{array}{l}\text { Organic } \\
\text { Content }(\%)\end{array}$ & $\begin{array}{l}\text { MIC of treated } \\
\text { mica }(\mu \mathrm{g} / \mathrm{mL})\end{array}$ & $\begin{array}{l}\text { Available antibacterial } \\
\text { concentration }(\mu \mathrm{g} / \mathrm{mL})\end{array}$ & $\begin{array}{l}\text { MIC of antibacterial } \\
\text { compound }(\mu \mathrm{g} / \mathrm{mL})\end{array}$ \\
\hline CTAB & 26.78 & 2 to 4 & $0.5-1$ & 4 \\
\hline C16-Q & 27.88 & 2 to 4 & $0.5-1$ & 8 \\
\hline C16-D & 27.11 & 4 & 1 & 4 \\
\hline $\mathrm{Ag}^{+}$ & - & 4 to 64 & - & 8 \\
\hline NOR & 11.25 & 32 & 3.5 & 0.5 \\
\hline
\end{tabular}

\section{Discussion}

The results obtained for the organically and silver-modified clays indicate that all samples show very good antibacterial activities. Two possible mechanisms can be responsible for the observed antibacterial activity. The first mechanism involves the immobilization of the bacteria on the surface of the clay. The affinity of bacteria for fluoromica can be as a result of two critical interactions: electrostatic attraction and hydrophobic interaction. Under physiological conditions, both fluoromica and bacterial cell surfaces are negatively charged (Nzengung et al., 1996; Stotzky et al., 1989). This prevents the attraction of bacteria to fluoromica. However, the exchange of clays with positively charged antibacterial agents at greater than the CEC produces a material that is positively charged. The charge of these exchanged clays enhances their ability to attract bacteria through electrostatic interactions. Introduction of norfloxacin and QACs with long alkyl chains also provides a hydrophobic character to the clays. These hydrophobic moieties on the clay surface can interact with the lipophilic components of the bacterial cell walls, such as lipoproteins, liposaccharides, and phospholipids. As a result of these two types of interactions, the bacteria are brought in close association to the surface of 
the exchanged clay, where the antibacterial agents exert their activity on the bacteria. This mechanism was first proposed by Herrera at al. and supported by the cetylpyridinium desorption studies. In the desorption studies, they found that the antibacterial activity was localized at the modified clay surfaces, as the washed clay particles produced reductions in bacterial counts, whereas the washed solutions did not. They also obtained electron micrographs of the treated clays, which showed that bacteria were adherent to the surfaces of the cetylpyridinium-exchanged clays (Herrera et al., 2000; Herrera et al., 2004). In our study, the antibacterial activities for all treated clays were maintained in the second trials as well as after several washings. The organic contents of the treated clays obtained from TGA thermograms also indicated that the amount of the organic content stayed pretty much the same after several washings. These are good indicators for the fact that the antibacterial activity occurs on the clay surface. The MIC values obtained against $S$. aureus and E. coli show very interesting trends. The minimum inhibitory concentrations of the antibacterial agents in the QAC-treated clays are at or below the MIC values of the original QACs. The explanation for this fact is that since QACs are in close proximity when they are attached to the clay surface, they show synergistic better activity against bacteria through enhanced electrostatic and hydrophobic interactions with bacterial cell surfaces.

The second mechanism involves the dissociation of the antibacterial agents from the clay surface and exertion of their antibacterial effects on bacteria in suspension. The zone of inhibition studies indicate that there are inhibition zones for all treated clays. This is a sign of the diffusion of the antibacterial agents from treated clays into the agar. However, the inhibition zones were very small in diameter for all treated clays except 
norfloxacin-treated clay. This could be because the norfloxacin diffuses more efficiently than the other compounds and/or because norfloxacin is less tightly bound to the surface of the clay. These results indicate that at least a small amount of antibacterial is being released into the TSA. TSA contains sodium chloride and other organic compounds, which could facilitate the exchange of cations on the fluoromica surface in the reverse direction.

\section{Conclusions}

In this work, various antibacterial compounds were efficiently exchanged with cations in fluoromica in order to obtain antibacterial fluoromicas. The treated fluoromicas showed excellent antibacterial activities. The antibacterial activity of the treated fluoromicas is mainly due to the attraction of the bacteria to the clay surface through electrostatic and hydrophobic interactions and exertion of the antibacterial effect of the antibacterial agents bound to the surface on bacteria. The small and continuous release of antibacterial agents from treated clays is other minor mechanism of activity. Since these materials show very good antibacterial activities, they offer excellent potential for long term effectiveness for surfaces, paints, water filtration, or as powdered delivery of antibacterials.

\section{Acknowledgements}

This material is based upon work supported by the National Science Foundation under MRSEC (Grant No. DMR 0213883). We also thank the NSF-MRI program (Grant No. DMR-0079450) for funding to upgrade and expand the NMR capability at USM. 


\section{References}

Alther, G., 2000. Bactericidal organoclay for water disinfection containing quaternary amine and iodine. US patent 6,165,485.

Baveja, J.K., Willcox, M.D.P., Hume, E.B.H., Kumar N., Odell, R., Poole-Warren, L.A., 2004. Furanones as potential antibacterial coatings on biomaterials. Biomaterials 25 , 5003-5012.

Baveja, J.K., Willcox, M.D.P., Hume, E.B.H., Kumar N., Odell, R., Poole-Warren, L.A., 2004. Biological performance of a novel synthetic furanone-based antimicrobial. Biomaterials 25, 5013-5021.

Birnie, C.R., Malamud, D., Schnaare, R.L., 2000. Antimicrobial evaluation of N-alkyl betains and $\mathrm{N}$-alkyl-N, $\mathrm{N}$-dimethylamine oxides with variations in chain length. Antimicrob. Agents Chemother. 44, 2514-2517.

Borman, S., 2002. Surfaces designed to kill bacteria. Sci. Tech. 80(22), 36.

Catauro, M., Raucci, M.G., Gaetano, F.D., Marotta, A., 2004. Antibacterial and bioactive silver-containing $\mathrm{Na}_{2} \mathrm{O} . \mathrm{CaO} .2 \mathrm{SiO}_{2}$ glass prepared by sol-gel method. J. Mater. Sci.Mater. Med.15, 831-837.

Chauhan, G.S., Singh, B., Dhiman, S.K., 2004. Functionalization of poly(4-vinly pyridine) grafted cellulose by quaternization reactions and a study on the properties of postquaternized copolymers. J. Appl. Polym. Sci. 91, 2454-2464.

Dibrov, P., Dzioba, J., Gosink, K.K., Häse, C.C., 2002. Chemiosmotic mechanism of antimicrobial activity of $\mathrm{Ag}^{+}$in vibrio cholerae. Antimicrob. Agents Chemother. 46, 2668-2670. 
Dizman, B., Elasri, M.O., Mathias, L.J., 2005. Synthesis, characterization, and antibacterial activities of novel methacrylate polymers containing norfloxacin. Biomacromolecules 6, 514-520.

Dizman, B., Elasri, M.O., Mathias, L.J., 2004. Synthesis and antimicrobial activities of new water-soluble bis-quaternary ammonium methacrylate polymers. J. Appl. Polym. Sci. 94, 635-642.

Drlica, K., 1999. Mechanism of fluoroquinolone action. Curr. Opin. Microbiol. 2, 504508.

Estevao, L.R.M., Mendonca-Hagler, L.C.S., Nascimento, R.S.V., 2003. Development of polyurethane antimicrobial composites using waste oil refinery catalyst. Ind. Eng. Chem. Res. 42, 5950-5953.

Guilbeaux, R., 1988. Biocidal clay thickening additive for an organic composition, specifically a cosmetic preparation. Eur. Pat. Appl. 265,101.

Heinz, H., Suter, U.W., 2004. Surface structure of organoclays. Agew. Chem. Int. Ed. 43, 2239-2243.

Heinz, H., Castelijns, H.J., Suter, U.W., 2003. Structure and phase transitions of alkyl chains on mica. J. Am. Chem. Soc.125, 9500-9510.

Herrera, P., Burghardt, R., Huebner, H.J., Phillips, T.D., 2004. The efficacy of sandimmobilized organoclays as filtration bed materials for bacteria. Food. Microbiol. 21, $1-10$.

Herrera, P., Burghardt, R.C., Phillips, T.D., 2000. Adsorption of Salmonella enteritidis by cetylpyridinium-exchanged montmorillonite clays. Vet. Microbiol. 74, 259-272. 
Hume, E.B.H., Baveja, J., Muir, B., Schubert, T.L., Kumar, N., Kjelleberg, S., Griesser, H.J., Thissen, H., Read, R., Poole-Warren, L.A., Schindhelm, K., Willcox M.D.P., 2004. The control of Staphylococcus epidermidis biofilm formation and in vivo infection rates by covalently bound furanones. Biomaterials 25, 5023-5030.

Lee, S.B., Koepsel, R.R., Morley, S.W., Matyjaszewski, K., Sun, Y., Russel A.J., 2004. Permanent, nonleaching antibacterial surfaces. 1. Synthesis by atom transfer radical polymerization. Biomacromolecules 5, 877-882.

Melaiye, A., Simons, R.S., Milsted, A., Pingitore, F., Wesdemiotis, C., Tessier, C.A., Youngs, W.J., 2004. Formation of water-soluable pincer silver(I)-carbene complexes: a novel antimicrobial agent. J. Med. Chem. 47, 973-977.

Murayama, H., Shimizu, K., Tsukada, N., Shimada, A., Kodama, T., Kitayama, Y., 2002. Photocatalytic degradation of hexachlorocyclohexane $(\mathrm{HCH})$ by $\mathrm{TiO}_{2}$-pillared fluorine mica. Chem. Commun. 22, 2678-2679.

Nzengung, V.A., Voudrias, E.A., Nkedi-kissa, P., Wampler, J.M., Weaver, C.E., 1996. Organic cosolvent effectson sorption equilibrium of hydrophobic organic chemicals by organoclays. Environ. Sci. Tech. 30, 89-96.

Oie, S., Ishitobi, J., Sawa, A., Tomita, M., Kamiya, A., 2004. In vitro bactericidal activity of antimicrobial agents against enterohaemorrhagic Escherichia coli. J. Antimicrob. Chemother. 54(5), 897-903.

Piddock, L.J.V., Jin, Y.F., Griggs, D.J., 2001. Effect of hydrophobicity and molecular mass on the accumulation of fluoroquinolones by Staphylococcus aureus. J. Antimicrob. Chemother. 47, 261-270. 
Richard, L., Samuel, F. 1997. The development and functions of silver in waterpurification and disease-control. Catal. Today 36, 107.

Rivera-Garza, M., Olguin, M.T., Garcia-Sosa, I., Alcantara, D., Rodriguez-Fuentes, G. 2000. Silver supported on natural Mexican zeolite as an antibacterial material. Micropor. Mesopor. Mat. 39, 431-444.

Samuel, U., Guggenbichler, J.P., 2004. Prevention of catheter-related infections: the potential of a new nano-silver impregnated catheter. Int. J. Antimicrob. Ag. 23:S1, 75-78.

Sauvet, G., Dupond, S., Kazmierski, K., Chojnowski, J., 2000. Biocidal polymers active by contact. V. Synthesis of polysiloxanes with biocidal activity. J. Appl. Polym. Sci. $75,1005-1012$.

Stotzky, G., 1989. Surface interactions between clay minerals and microbes, viruses, and soluble organics, and the probable importance of these interactions to the ecology of microbes in soil. In: Berkeley, C. W. (Ed.), R. Microbial Adhesion to Surfaces. Ellis Norwood, Chichester, England, pp. 231-247.

Tamura, K., Inoue, H., Noguchi, M., Ebata, T., 2000. Organic-inorganic composites, synthetic resin compositions containing the same, and manufacture of the composites. Jap. patent 2000053805 . 